\title{
83. Pseudolarix nipponica sp. nov., from the Palaeogene Noda Group, Northeast Japan*)
}

\author{
By Tatsuaki KImURA and Junji HoRIUCHI \\ Tokyo Gakugei University \\ (Communicated by Teiichi Kobayashi, M. J. A., Oct. 12, 1978)
}

The Palaeogene Noda Group is distributed along the northeastern Pacific coast of Iwate Prefecture $\left(40^{\circ} 07^{\prime}-40^{\circ} 13^{\prime} \mathrm{N}\right)$, Japan. This group has been considered as a whole to be of non-marine origin and includes a succession of beds rich in plants. From the Minato Formation, ${ }^{* *}$ ) a lower part of this group, we collected many conifers placed in 5 families and 10 genera and other plants including many angiosperms.

This paper deals with the description of Pseudolarix nipponica newly recognized by us from the Minato Formation.

\section{Order Coniferales, Family Pinaceae \\ Genus Pseudolarix Gordon, 1858}

This genus is now monotypic, only Pseudolarix kaempferi Gordon is known to be in its habitat at the highland (1000-1200 $\mathrm{m}$ high) in Guang xi and Zhe jiang, southern and eastern China. The fossil records of this genus have been known stratigraphically since the Lower Cretaceous and geographically in the Northern Hemisphere as shown by Florin (1963, p. 250 and fig. 56).

Pseudolarix has been described many times as a fossil, but this is the first account that gives information about the cuticle. This may be because, like most deciduous conifers, Pseudolarix leaves have thin, delicate cuticles easily destroyed in maceration. The cuticles here described were prepared by the maceration with $\mathrm{HNO}_{3}+\mathrm{KClO}_{3}$ followed by diluted $\mathrm{NaOH}$.

Pseudolarix nipponica Kimura and Horiuchi sp. nov.

Figs. 1-7

Holotype: Branchlet, MI-711; leaves, MI-714; cuticles of leaf, slide no. MI-717a.

Horizon: Palaeogene Minato Formation, Noda Group, Iwate Prefecture.

Repository: All specimens and slides here described are de-

*) Studies on Japanese fossil conifers-I. Supported by the Scientific Research Fund of the Ministry of Education, Japan; no. 154290 (1978).

**) 野田層群, 港層 

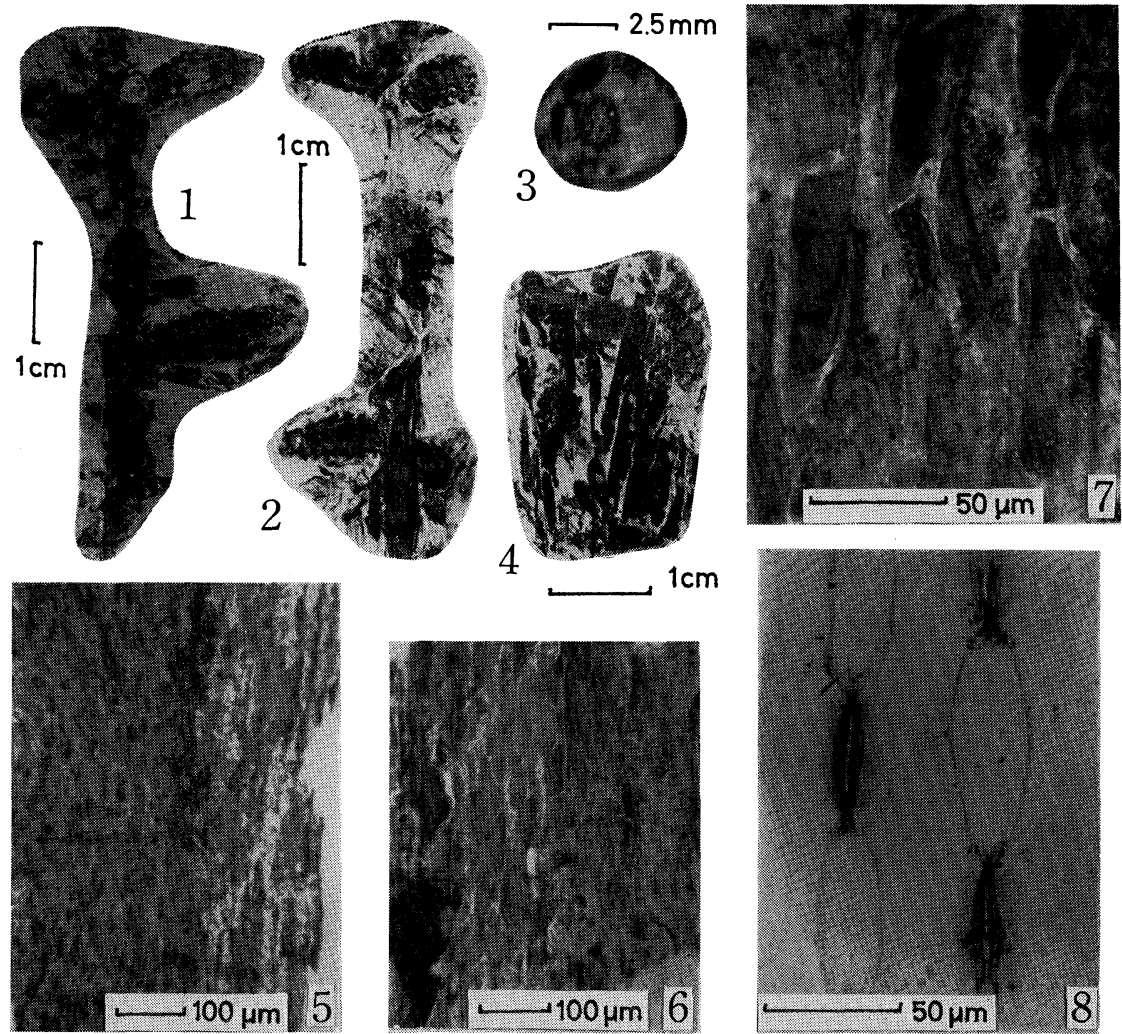

Figs. 1-7. Pseudolarix nipponica sp. nov. 1-2: Branchlets. Spirally disposed triradiate and barrel-shaped short shoots with distinct annual rings of leaf-scars, on a long shoot. (Fig. 1, holotype of branchlet, MI-711; Fig. 2, counterpart of Fig. 1). 3: A polished cross section of a short shoot prepared from Fig. 2. 4: Crowded detached leaves (holotype of leaves, MI-714). 5: Upper cuticle (slide no. MI-717a). 6-7: Lower cuticle (slide no. MI-717a).

Fig. 8. Pseudolarix kaempferi Gordon (extant). Lower cuticle, showing three stomata and their subsidiary cells. (Prepared from the specimen cultivated at the Asakawa Arboretum, Forestry and Forest Research Institute, Tokyo.)

posited in the Department of Astronomy and Earth Sciences, Tokyo Gakugei University.

Origin of specific name: Nippon means Japan in Japanese.

Occurrence: Common.

Diagnosis: Branchlets; long shoots $5 \mathrm{~mm}$ across, with smooth surface and sending nearly perpendicularly off spirally disposed short shoot sets, the distance between successive sets being $2.7-3.6 \mathrm{~cm}$. Each set consisting mostly of triradiate barrel-shaped short shoots, disposing with very short intervals on the long shoot, the maximum distance of them being $7 \mathrm{~mm}$ long. Short shoots $8-27 \mathrm{~mm}(16 \mathrm{~mm})$ 
long and $3 \mathrm{~mm}$ across at base and $4-7 \mathrm{~mm}(5 \mathrm{~mm})$ at middle, and ornamented with the distinct annual rings of leafscars, typically 8-11 in number. Short shoots in cross section with a large pith inside, a thin layer of xylem (phloem unrecognized), inner cortex and a thick outer cortex (resin canals or sclerids unrecognized). Leaves; linear lanceolate in form with a strong median vein, about $3 \mathrm{~cm}$ long and $2.8 \mathrm{~mm}$ wide at the widest portion.

Cuticle hypostomatic. Upper cuticle consisting of linear and rectangular normal cells, $20 \mu$ wide. Cell walls very thin and straight. Lower cuticle consisting of normal cells zones and stomate complex forming stomate zones being parallel to the elongation of leaf. Each stomate zone consisting of four or more stomate rows. Stomata $35 \mu$ long and $11.3 \mu$ wide. Polar subsidiary cells elongate-oblong in form, $100 \mu$ long and $21 \mu$ wide at the widest portion, touching with straight end walls to the stomata. Aperture parallel to the orientation of stomate row. Stomata and polar subsidiary cells alternating to form a single stomate row. Lateral subsidiary cells similar in form to polar cells, touching with their one lateral side to the stoma and its polar cells, and with their another side generally to the lateral ones in the adjoining stomate row back to back. Cell walls straight. Normal cells forming normal cells zone, similar in form to those of upper cuticle, distributing between the stomate zones, but quite few in the stomate zones. (Fructification not known.)

Description: Several branchlets with short shoots and many detached leaves were obtained. Leaves with cuticles are all detached but are closely associated with the branchlets in occurrence.

Fig. 1 (Holotype of branchlet) shows a well preserved branchlet in which triradiate short shoot sets with long intervals on a long shoot and distinct annual rings of leaf-scars on the barrel-shaped short shoot are clearly seen as well as in its counterpart shown in Fig. 2. We could not make the phyllotaxis of short shoot clear. Fig. 3 shows a polished cross section of a short shoot prepared from one of them shown in Fig. 2, $2.6 \mathrm{~mm}$ in diameter. In this section, central pith, about $0.62 \mathrm{~mm}$ in diameter, wood, about $0.12 \mathrm{~mm}$ wide (dark ring) and thick cortex (light part) surrounding unevenly the wood are seen. Under magnification radially disposed cells are recognizable in the wood. Unfortunately we could not make a section of sufficiently good quality to show finer anatomical features.

Detached leaves are generally preserved in crowds but fragmentarily as shown in Fig. 4 (Holotype of leaves). Cuticles of leaves are mostly delicate and fragile. Fig. 5 shows the upper cuticle consisting of elongated normal cells with straight cell walls. We could not know their length, because their end walls were always destroyed 
on the course of chemical maceration. Fig. 6 shows the lower cuticle. In this figure, the left half shows the stomate zone consisting of stomate rows as partly shown in Fig. 7 further enlarged, and the right half the zone consisting of normal cells faintly preserved as in the case of the upper cuticle. The structure of stomate row is similar in form to that of extant Pseudolarix kaempferi, but the stomata of present material are generally far smaller in size than those of the extant species as partly shown in Fig. 8.

Comparison and discussion: Judging from its barrel-shaped short shoots ornamented with distinct annual rings of leaf-scars both characterizing Pseudolarix and the agreement of its leaf-cuticles to those of extant Pseudolarix, it is certain that the present material belongs to this genus.

There is no possibility that the present material belongs to Larix, because in Larix, short shoots are not barrel-shaped but cylindrical and the polar cells are not elongated but typically oval and are different in form from those of Pseudolarix (Florin, 1931, p. 328).

Jähnichen and Kahlert (1972) gave a useful list of fossil Pseudolarix species and its allied forms and described Mesolarix mongolica based only on the branchlets from the Jurasso-Cretaceous (?) of Mongolia. More recently Pseudolarix bacharevii was described by Vakhrameev and Lebedev (1976) from the Upper Cretaceous Amkin Formation, West Priokhotie.

So far as the form of short shoots and leaf-cuticles are concerned, Pseudolarix nipponica resembles extant Pseudolarix kaempferi. But it is distinguishable from the extant species as follows: (1) Its stomata are generally smaller than those of extant species, only twothird as large, comparing with those of the extant species; (2) so far as we know, in the extant species, short shoots are spirally disposed solely at long intervals, instead of forming triradiate short shoot sets.

In the forms of short shoots and leaves, Pseudolarix nipponica resembles Pseudolarix bacharevii Vachrameev and Lebedev, and $P$. dorofeevii Samylina from the Lower Cretaceous of Aldan (Samylina, 1963), of Southern Primorye (Krassilov, 1967), and of Priokhotie (Lebedev, 1974).

Many branchlets without leaves have been recorded under the generic name of Mesolarix (Jähnichen and Kahlert, 1972), Pityocladus (Vassilevskaja and Pavlov, 1963), Pseudolarix (many authors, see Jähnichen and Kahlert, 1972, table 1), etc. They are mostly indistinguishable from those of Pseudolarix nipponica only by their external form.

Archaeolarix argunensis based on branchlets and leaves, described by Teslenko (1970) from the Lower Cretaceous Argun Formation, 
Eastern Baikal, on the border of NE-China, seems to be rather close to Larix in external appearance.

In Japan, Pseudolarix was first described by Miki (1941) as Pseudolarix kaempferi based on branchlets, detached leaves, conescales and seeds, but without leaf-cuticles, from the Neogene strata in Osaka, Aichi and Tochigi Prefectures. Tanai and Onoe (1961) described Pseudolarix japonica based on a single cone-scale from the Mio-Pliocene bed on the bordered area between Tottori and Okayama Prefectures and afterwards Tanai (1961) included Miki's Pseudolarix kaempferi into their P. japonica as synonymous.

Miki's branchlets and leaves are distinguishable from Pseudolarix nipponica by their much smaller size. Pseudolarix nipponica is the oldest Pseudolarix record in Japan.

Acknowledgements. We first express our sincere gratitude to Professor Emeritus Thomas M. Harris, F.R.S. of the University of Reading for his very helpful suggestions and kindest reading over the present manuscript. We are indebted to Professor Emeritus T. Kobayashi, M. J. A., of the University of Tokyo for giving us the facilities to publish this paper. We also thank Mr. Y. Kobayashi of the Asakawa Arboretum, Forestry and Forest Research Institute for giving us the extant Pseudolarix specimens.

\section{References}

Florin, R. (1931): Untersuchungen zur Stammesgeschichte der Coniferales und Cordaitales. K. Svensk. Vet.-Akad. Handl., Stockholm, 10(1), 1-588, pls. 1-58.

- (1963): The distribution of conifer and taxad genera in time and space. Acta Horti Bergiani, 20(4), 121-312.

Jähnichen, H., and Kahlert, E. (1972): Über eine mesozoische Flora aus der mongolischen Volksrepublik. Geol., 21(8), 964-1001, incl. pls. 1-6.

Krassilov, V. A. (1967): Early Cretaceous flora from Southern Primorye and its significance for stratigraphy. Far East Geol. Inst., Siber. Br., Acad. Sci. USSR, Moscow, 1-248, pls. 1-93 (in Russian).

Lebedev, E. L. (1974) : Albian flora and Lower Cretaceous stratigraphy of West Priokhotie. Acad. Sci. USSR, Trans., no. 254, 1-147, incl. pls. 1-31 (in Russian).

Miki, S. (1941): On the change of flora in Eastern Asia since Tertiary period (1). The clay or lignite beds flora in Japan with special reference to the Pinus trifolia beds in Central Hondo. Japan. J. Bot., 11, 237-303, pls. 1-7.

Samylina, V. A. (1963): Mesozoic flora of the lower course of the Aldan River. Palaeobot., Komarov Bot. Inst., Acad. Sci. USSR, ser. 8, 4, 59-138, pls. 1-37 (in Russian).

Tanai, T. (1961) : Neogene floral change in Japan. J. Fac. Sci., Hokkaido Univ., ser. 4 (Geol. Min.), 11 (2), 119-398, pls. 1-32.

Tanai, T., and Onoe, T. (1961) : A Mio-Pliocene flora from the Ningyo-toge area on the border between Tottori and Okayama Prefectures, Japan. Rep. Geol. Surv. Japan, no. 187, 1-63, pls. 1-18.

Teslenko, Yu. V. (1970): On the geological history of larchs and pseudolarchs. J. Palaeont., Acad. Sci. USSR, 1970-2, 98-104, pl. 13 (in Russian). 
Vakhrameev, V. A., and Lebedev, E. L. (1976): A new Pseudolarix from the Upper Cretaceous of the Northeastern USSR. Ibid., 1976-4, 127-130 (in Russian).

Vassilevskaja, N. D., and Pavlov, V. V. (1963) : Stratigraphy and flora from the Cretaceous beds of Lena-Olenek region of Lena Coal-Basin. II Problems of oil and gas content beds in Arctica. Bull. Inst. Arct. Geol., Min. Geol. Protect. Undergr. Res., USSR, no. 128, 1-95, pls. 1-49 (in Russian). 